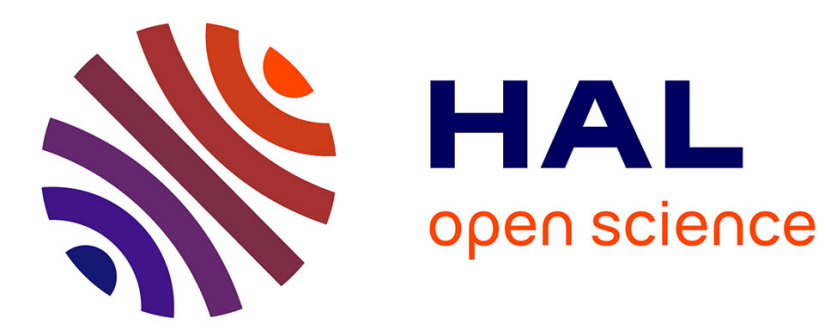

\title{
Now in the speech of newcomers to Ireland
}

\author{
Bettina Migge
}

\section{To cite this version:}

Bettina Migge. Now in the speech of newcomers to Ireland. Amador-Moreno, Carolina P., McCafferty, Kevin \& Vaughan, Elaine. Pragmatic Markers in Irish English, John Benjamins, pp.390-407, 2015, 9789027256638. hal-01494533

\section{HAL Id: hal-01494533 https://hal.science/hal-01494533}

Submitted on 23 Mar 2017

HAL is a multi-disciplinary open access archive for the deposit and dissemination of scientific research documents, whether they are published or not. The documents may come from teaching and research institutions in France or abroad, or from public or private research centers.
L'archive ouverte pluridisciplinaire HAL, est destinée au dépôt et à la diffusion de documents scientifiques de niveau recherche, publiés ou non, émanant des établissements d'enseignement et de recherche français ou étrangers, des laboratoires publics ou privés. 


\title{
Now in the speech of newcomers to Ireland
}

\author{
Bettina Migge, University College Dublin
}

\section{Introduction}

The last roughly twenty years have seen a steady rise in research on varieties of English as spoken in Ireland (e.g. Filppula 1999; Hickey 2005; Corrigan 2010; Amador-Moreno 2010). One line of research that has been particularly fruitful is the corpus-based investigation of pragmatic aspects of varieties of Irish English. While early work in this area examined hedging phenomena (Farr and O'Keeffe 2002; Farr et al. 2004), more recent research has been exploring a range of issues such as politeness strategies and relational work in different interactional contexts (Clancy 2005, 2011; Farr 2005), the uses, meanings and functions of silence and mitigation (Kallen 2005), vocatives (Murphy \& Farr 2012), different types of questions (O'Keeffe 2005) and discourse markers (Amador-Moreno 2005; Clancy \& Vaughan 2012). Most of these phenomena were examined on the basis of the one million word Limerick Corpus of Irish English (LCIE) which consists of a diverse set of recordings of naturally occurring speech from all over Ireland (Farr et al. 2004). Although Ireland underwent significant social change between the 1990s and 2007 due to both unprecedented levels of economic growth and immigration to Ireland, ${ }^{1}$ research on language use in general and pragmatics in particular continues to primarily focus on the speech of people who speak varieties of Irish English as their main or only language. Aside from some recent work on the use of the discourse marker like among a small group of Polish immigrants to Ireland (Nestor et al 2012), the use of various discourse markers (like, you know, I mean) by a select group of Polish and

\footnotetext{
${ }^{1}$ At the height of the boom, the foreign population of Ireland nearly doubled within the space of four years: from $7 \%$ or 274,000 people in 2002 to $13 \%$, or 420,000 people in 2006. Until recently, UK citizens constituted the largest group of newcomers (Gilmartin \& Mills 2008), however, recent census data suggests that people from Poland exceed UK citizens. Other newcomers came from a variety of EU 15 (e.g. France, Germany, Italy, Spain, the Netherlands) and EU 25 (e.g. Latvia, Lithuania, Slovakia) countries, and from countries outside of Europe such as Australia, the United States, Nigeria and India.
} 
Chinese newcomers (Diskin 2013) and some work on newcomers' attitudes to Irish English (Migge 2012), we know relatively little about adult immigrants' engagement with the varieties of English spoken in Ireland.

This paper aims to make a contribution towards filling this gap by investigating newcomers' uses of the multifunctional element now. Focusing on the speech of a total of 59 people who have made Ireland their home, it examines whether and to what degree newcomers are acculturating to local language practices and are adopting the different uses of now. Although discourse markers (e.g. Schiffrin 1987; Brinton 1996; Aijmer 2002) and research on pragmatic competence more broadly (e.g. Anchimbe \& Janney 2011) has come to figure more prominently in sociolinguistic investigations, there is very little research on their use by language learners (Romero Trillo 2002; Müller 2005) and by people who are learning a second dialect (of English). According to Müller (2005: 1), the lack of research is somewhat surprising because "pragmatic competence in terms of knowing the cultural values of the second language, for example, is recognized as being essential for successful communication" in Second Language Acquisition studies. Acquisition of discourse markers unlike that of structurally embedded items is highly dependent on exposure to interactions in the language as they are generally not easily accessible to conscious reflection:

If a foreign language learner says "five sheeps" or "he goed", he can be corrected by practically every native speaker. If, on the other hand, he omits a well, the likely reaction will be that he is dogmatic, impolite, boring, awkward to talk to etc., but a native speaker cannot pinpoint an 'error' (Svartvik 1980: 171).

Learner's relative degree of usage of discourse markers thus functions as an index of learners' level of exposure to and contact with the language and, by extension, their relative degree of integration.

Now is an interesting case. It is commonly used in varieties of English. However, despite its ubiquity, there appear to be certain uses of now that both researchers (Clancy and Vaughan 2012: 232-3) and speakers and non-speakers of varieties of Irish English appear to see as characteristic of Irish English. For instance, when asked about what they see as distinctive about Irish ways of speaking English, several of the newcomers to Ireland whose data will be examined in this study singled out like, now and would as being emblemic of Irish English. A woman of Nigerian origin (A), for 
instance, explained that certain of the uses of now in Irish English are distinctive and that she uses them only in specific contexts, namely when interacting with Irish people.

\section{Extract $(1)^{2}$}

A: $\quad[\ldots]$ The way they use like, I don't now how to ex, explain that, in some instance where they would, em, say something and they would use that word now, I'm trying to think and, em, I'm thinking now.

$[\ldots]^{\prime} I$ 'm after', yeah, 'I'm after...', yeah, oh yeah, that's another thing, and then now as well...

B. Do you think..?

A. $\quad$...they use now as well.

B. Right, now, yeah, 'now'.

A. 'We'd better fight now, or...', em.

B. 'Now get your bag'.

A. Or 'do something now', something, you know, those expressions, but I would only find myself, you know, saying something like that if I'm talking to an Irish person, or, I'm in a group where the Irish people are [...] (N2)

Section two of the paper presents the data of this study. Section three reviews the concepts of discourse and pragmatic marker and current knowledge about the uses and functions of now in English and Irish English in particular. The fourth section discusses the distribution of now in the interviews with newcomers to Ireland, focusing on those uses that are emblemic of Irish English. The final part summarizes the findings and discusses their implications.

\section{The Data for the Study}

The bulk of the data for this study come from semi-guided interviews with recent newcomers to Ireland. ${ }^{3}$ We asked interviewees to tell us about a range of issues

\footnotetext{
${ }^{2}$ Note that all examples from my own data are presented in a clean format because the data have to date not been assembled into a tagged corpus. The examples taken from the ICE-Ireland corpus and those quoted from the LCIE appear in tagged format.
} 
relating to their life in Ireland such as their reasons for coming to Ireland, their experiences with finding work and in the work place, their contacts with Irish and non-Irish people, their leisure activities, their experiences with government services, their neighborhoods, their views about Irish culture, Irish and English, their future plans and the impact of the current recession on their lives.

Participants had either arrived in 2004 or in 2007 and were identified using three key methods: snowballing, flyers, and online recruitment via a number of on-line forums for expatriates. Most participants were interviewed twice over a period of two years and interviews lasted about an hour. Participants are representative of Ireland's immigrant population. They consisted of thirty-six women and twenty-four men and their ages ranged from 23 to 68 years of age, with the overwhelming majority in their twenties and thirties. Interviewees originated from different European countries, ${ }^{4}$ Australia, North America, India, Uganda and South Africa, and lived in a variety of locations throughout Ireland. Many of the interviewees held a third level degree or had had professional training prior to arriving in Ireland and a small number of them also held a fourth level degree. In Ireland, they worked in a variety of occupational sectors (Table 1). Some of the interviewees held an occupation commensurate with their educational qualification and/or similar to the one that they held prior to coming to Ireland, while others had to, at least initially, work in jobs below their level of qualification and experience. Due to issues with recording and transcription quality with some recordings, only 101 interviews involving 54 interviewees - seven interviewees were only interviewed once instead of twice - were analyzed linguistically for this project.

Table 1: Occupation of interviewees at time of interview

\begin{tabular}{|l|l|l|}
\hline Employment Sector & $\begin{array}{l}\text { No. of } \\
\text { Interviewees }\end{array}$ & Type of Job \\
\hline Construction & 5 & $\begin{array}{l}\text { Architect, engineer, technician, } \\
\text { administrator }\end{array}$ \\
\hline
\end{tabular}

\footnotetext{
${ }^{3}$ The IRCHSS-funded project was entitled Towards a dynamic approach to research on migration and integration (PI: Mary Gilmartin, University of Maynooth) and ran from December 2008 to December 2010.

${ }^{4}$ They came from the France, Finland, Germany, Italy, the Netherlands, Poland, Slovakia, Slovenia, Spain, and UK.
} 


\begin{tabular}{|l|l|l|}
\hline $\begin{array}{l}\text { Wholesale and retail } \\
\text { trade }\end{array}$ & 3 & Sales \\
\hline Hotels and restaurants & 6 & Porter, waiter, receptionist, bar staff \\
\hline $\begin{array}{l}\text { Banking and financial } \\
\text { services }\end{array}$ & 4 & Bank, insurance, administrator \\
\hline $\begin{array}{l}\text { Real estate, renting and } \\
\text { business activities }\end{array}$ & 11 & $\begin{array}{l}\text { Administrator, call-centre operative, IT } \\
\text { project manager }\end{array}$ \\
\hline $\begin{array}{l}\text { Education } \\
\text { Health and social work }\end{array}$ & 4 & Lecturer, teacher, administrator \\
\hline $\begin{array}{l}\text { Other community, social } \\
\text { and personal service } \\
\text { activities }\end{array}$ & 4 & Doctor, nurse, therapist \\
\hline Students & 6 & Childcare, trade union, charity \\
\hline Other & 3 & Part-time work in childcare, retail \\
\hline Not employed & 7 & Consultant, business owner, artist \\
\hline
\end{tabular}

The study also includes recordings from another research project that focused on the linguistic integration of African newcomers to Ireland. ${ }^{5}$ For this project, a total of thirteen people living in the Dublin area were accessed through a variety of community groups and interviewed once. Interviewees worked in retail, community services, were full time students or did voluntary work because as asylum seekers they were barred from working. While these interviews also focused on people's lives in Ireland, they included more detailed discussions of people's linguistic backgrounds and linguistic ideologies. For the purpose of this project, five of the thirteen recordings were analyzed in detail. ${ }^{6}$

As discussed in Migge (2012: 315f), interviewees had a range of levels of English. Those who originated from North America, Australia and the UK generally presented themselves as monolingual speakers of English. Interviewees from India and Africa had usually received all or important parts of their education through English but

${ }^{5}$ The project was funded by the UCD Seed funding scheme and was entitled Linguistic practice and social identity in the context of migration in contemporary Ireland. It ran during 2006.

${ }^{6}$ A total of 101 transcripts/recordings from the first project and 5 transcripts/recordings from the second project were linguistically analyzed for this paper. 
asserted also speaking other languages. However, only those who came with their families appear to regularly use one or more languages besides English in Ireland. The people from continental Europe, francophone Canada and China generally learned English as a foreign language later in life, but in most cases prior to coming to Ireland. Although interviewees had various levels of competence in English, they were all able to engage in the interview process without any difficulty. Only a small number of Polish and Italian interviewees arrived in Ireland with next to no competence in English and essentially learned English in Ireland. The majority of interviewees relied on interactions with others, subject-based study, reading of books in English and/or watching of English-medium films in order to improve their level of English. Those who did take English language classes usually did so for only a short period of time and generally after they had achieved a certain level of fluency. Formal instruction was seen as a way of addressing remaining stylistic and grammatical shortcomings and of obtaining formal certification to be used for professional advancement. All interviewees asserted that they had very little precise knowledge of Irish English on arrival in Ireland and initially struggled to understand locals' language use.

\section{The research on now}

Since the data analysis in this paper will particularly focus on now's non-temporal or discursive uses, I briefly discuss the concept of discourse marker before reviewing the literature on now.

\subsection{Discourse markers}

According to Müller (2005: 2) research on discourse markers also variously referred to as discourse particles (Aijmer 2002) or pragmatic markers (Brinton 1998) started with Robin Lakoff's (1973) work on sentence initial why and well. Since that time a fair amount of research has been carried out with a view to capturing their nature (e.g. Schiffrin 1987; Aijemer 2002). However, instead of generating a definitive set of defining characteristics, research to date has highlighted their heterogeneous nature. For one, they originate from different syntactic classes such as conjunctions, adverbs 
and prepositional phrases (Fraser 1999: 946) and belong to different lexical classes. They also do not have a single linguistic structure. Some of them are single morphemes such as well, like, while others are phrasal elements such as I mean and you know in English. Moreover, while they appear to be susceptible to phonological reduction, not all of them have or will necessarily undergo it. Discourse markers tend to be quite frequent in spoken, conversational discourse, but they are also found in written discourse, though to date little research has been done on their uses and frequency in literature (but see Amador-Moreno 2005, 2012).

Researchers furthermore agree that discourse markers are independent of sentential structure because their removal from an utterance does not render it syntactically ungrammatical. This is an important characteristic that distinguishes discourse markers from their non-discourse marker homonyms. Another distinctive property relates to their function. Fraser (1999), building on Schiffrin's (1987) notion of discourse coherence, argues that their function is mostly procedural: "With certain exceptions, they signal a relationship between the segment they introduce, S2, and the prior segment, S1.” (p. 950). ${ }^{7}$ They provide insights into an utterance's place in the discourse structure and signal changes in the framing of an utterance. They guide the interpretation of an utterance such as an utterance's illocutionary force, provide cues as to how an utterance links to the context and/or its relationship to the textual sequence in which it occurs. Discourse markers are generally found in utterance initial position as they introduce S2. However, they may also be found in utterance medial or final position (Fraser 1999: 938).

Although the term discourse marker has often been used as a cover term to refer to all elements that contribute to the pragmatic interpretation of an utterance, it is important to distinguish two broad types of markers because they perform different functions. While discourse markers as defined above have a procedural meaning in that they establish linkages between utterances, what I will refer to as pragmatic markers operate on the interpersonal level. They give insights into the power relationships at play, interlocutors' relative status and cultural norms of communication. The clause-final use of maybe with requests or tag questions with declarative sentences, for instance, is linked to negative politeness and establishes a distance relationship.

\footnotetext{
${ }^{7}$ See also e.g. Blakemore (1992) on this issue.
} 


\section{2. Current knowledge on now}

Descriptive works on English generally describe now as a circumstantial adverb that indexes the temporal circumstances of an activity. It locates an event or state working at a certain location, being hungry, availability to speak - at the present time (1).

(1) a. $<\#>$ Yeah $<$, > yeah $<$, > yeah $<\#>$ I thought I didn't like working there but now I've decided that I do. (ICE-Ireland, S1A-057)

b. God I'm so hungry now I'd love to go for my dinner. (ICE-Ireland, S1A-046) ${ }^{8}$

c. Now isn't a good time to speak to him.

(http://dictionary.cambridge.org/dictionary/british/now 1)

It is also used to set up temporal relationships between utterances. In (2) now indicates that "getting dark" followed a previously mentioned event.

(2) It was getting dark now and we were tired. (http://dictionary.cambridge.org/dictionary/british/now 1)

Now is also used to indicate a temporal sequence. In (3) now indexes that being a vegetarian started ten years ago and that this state of affairs is still on-going.

(3) She's been a vegetarian for ten years now.

(http://dictionary.cambridge.org/dictionary/british/now 1)

Now as a circumstantial adverb is very frequent in spoken discourse, particularly in conversational interactions, and may occur in a variety of positions within the utterance such as utterance initially, medially or finally.

\footnotetext{
${ }^{8}$ ICE-Ireland is the Irish part of the Internation Corpus of English. It consists of transcripts of 300 spoken and 200 written text samples collected in Ireland specifically put together for the purpose of linguistic analysis (http://www.qub.ac.uk/sites/ICE-Ireland/).
} 
Now also performs various discursive functions. As a discourse marker it occurs in utterance initial position, is de-accented and unstressed, part of a larger intonational unit and may collocate with other discourse makers. According to Schiffrin (1987: 44), now's discursive meanings are linked to now's deictic meaning. Like temporal now, which is a proximal deictic that locates "an utterance in a ego-centered space, i.e. a space dominated by the producer, rather than the receiver, of an utterance" (Schiffrin 1987:245), now in its discursive uses is also ego-centered, focusing attention on the speaker's view and what they have to say. Discursive now, like other proximal deictics is also evaluative: "now is used to highlight interpretive glosses for one's own talk which a speaker him/herself favors." (Schriffrin 1987: 245). Schiffrin (1987) identifies two broad uses of discourse marker now. First, it is found "in discourse[s] in which the speaker progresses through a cumulative series of subordinate units" (Schiffrin 1987: 232) such as lists, arguments and comparisons. In this case now helps to overtly structure the discourse by introducing or highlighting subparts of a comparison (4) or argument (5).

(4) a. It's nice there.

b. Now our street isn't that nice. (Schiffrin 1987: 231)

(5) a. They have an open classroom at Lansdon.

b. Now there's lots of the mothers in that room are very upset about it.

c. I'm not. (Schiffrin 1987: 234)

Second, now also marks pivotal shifts in the participation framework or footing of an utterance, changing "the mode through which the speaker is related to the information being presented" (Schiffrin 1987: 240). It signals a (momentary) change in conversational activity (Clancy \& Vaughan 2012: 228) and functions to clear "a bit of conversational space" (Biber et al. 1999: 1088). For instance, in (6) it marks a shift from a declarative sentence to an interrogative one that enquires about reception and understanding on the part of the hearer.

(6) They're using socialism t' fight capitalism. Now can you understand that? (Schiffrin 1987: 240) 
In (7) three people are talking about the substandard conditions that an elder has to suffer in a retirement home and the reason for that. Presentation of the reason for the elder's suffering - the elder's stinginess - is set off from the presentation of the conditions using utterance initial now.

(7) $<$ S1A-055\$A $><\#><$ unclear $>$ several words $<$ /unclear $><\#>$ A place like Saint Ita 's sure would be ideal for the likes $<\{><[>$ of him $</[>$

$<$ S1A-055\$B $><\#><[>$ Yeah $</[></\{>$

$<$ S1A-055\$E $><\#>$ But you know it 's cruel where he 's above in Mallow now like $<\#>$ And he 's in that ward just there 's three beds here $<,>$ three facing him three behind him and this kind of thing like $<\#>$ Now he has plenty of money like but he wouldn't pay to go into a home $<\#>\mathrm{He}<\{><[>$ wouldn't pay to have a phone below now $</[>$ (ICE-Ireland, S1A-055)

Aijmer (2002: 92) also points out that besides introducing a different conversational activity, now is also used to intensify or highlight a subjective opinion particularly in a conflictual situation:

(8) ^none of whom will :spleak to each_other\# and ^all of whom want to cut each other's thrloats\#

nnow! I think this is a :very bad thling\# -

${ }^{\wedge}$ bad thing for British demlocracy\# -

I [e] . ^ watch I [we] I'm ^

to have ${ }^{\wedge}$ watched the !Labour . the ${ }^{\wedge}$ Lliberal_Party\#

(5.5 683-88)

The latest research on now, Schourup (2011), attempts to capture the discursive function of now from a relevance theoretic perspective without reference to the notion of local coherence. He argues that now encodes a procedural constraint roughly along the following lines: "Process the utterance in a context that is in part significantly ('noteworthily') new with respect to assumptions already highly accessible" (Schourup 2011: 2121). From this perspective now creates the "impression of interutterance coherence indirectly" because interpretation of utterances headed by now is 
contingent upon assumptions that emerged in the preceding context (Schourup 2011: 2128).

Research to date (e.g. Schiffrin 1987; Aijmer 2002; Schourup 2011) has generally focused on now's use in utterance initial position. However, Clancy \& Vaughan's (2012: 229, 236ff) work on now in Irish English shows that now also performs nonetemporal functions in utterance final position. In this position, it has the properties of a pragmatic marker. When it co-occurs with other markers of affective meaning, it is used as a marker of affect intensification. Take for instance example (9) from the LCIE corpus. Here now highlights or intensifies the negative feelings expressed by lunacy.

(9) $<$ Speaker 1 $>\quad$ No I'd never do that.

$<$ Speaker 2> I'll go.

$<$ Speaker 1 $>\quad$ Sarah I wouldn't do it.

$<$ Speaker 2> I always wanted to do that.

$<$ Speaker 3> It's lunacy now.

$<$ Speaker 1> I wouldn't do it. (Clancy \& Vaughan 2012: 229)

The intensification function of now is also found in (some) other varieties of English such as English as spoken in the UK but now appears utterance initially rather than finally in these varieties. In contexts in which now occurs in conjunction with facethreatening activities such as challenges, disagreements, evaluations and orders, it functions as a hedge (Clancy \& Vaughan's 2012: 238). In these instances, where it often also co-occurs with other hedges, it mitigates the face-threat to the hearer's face that is inherent in such activities. It "downtone[s] the illocutionary force of an utterance allowing the speaker to weaken his/her commitment to its propositional content." (Clancy \& Vaughan 2012: 237). This usage is evident in the discussion about a student loan application (10) from the ICE-Ireland corpus. Speaker C is urging a bank official to process the application quickly because he is running out of money. A is taking this request for faster processing as a face-threat and reprimands $\mathrm{C}$, ordering him to avoid unfriendliness. $\mathrm{C}$ mitigates the face-threat inherent in the order by postposing now to the command.

(10) $<$ S1A-053\$C $><\#><$ [ $>$ So I said $</[></\{>$ it 'll be another fortnight $<\#>$ Well do you 
think you could do it a bit faster like you know <\#> I 've got no money here

$<$ S1A-053\$A $><\#>$ Don't be rude now $<\#>$ Sure you 're on the list $<\#>$ We 're doing the best we can $<\&>$ laughter $</ \&>$

$<$ S1A-053\$C $><\#>$ And then my money ran out so I banged down the phone and said shit (ICE-Ireland, S1A-053)

Clancy \& Vaughan (2012: 235) argue that the use of now as a hedge is unique to Irish English and contributes to the high frequency and salience of now in Irish English as opposed to British spoken English, for instance. They argue that now's use as a utterance final hedge contributes "towards minimising power", underscoring "a crucial characteristic of the pragmatic system of Irish English: the emphasis on solidarity and corollary downtoning of power, both actual and conversational." (Clancy \& Vaughan 2012: 240; see also Farr \& O'Keeffe 2002 and Kallen 2005).

Clancy \& Vaughan (2012) also highlight yet another function of now that appears to be particular to Irish English, namely its use as a presentative marker. In this function, now makes an entity in the real world salient to the discourse by pointing to it. Example (11) is an example of this usage of now. Its use makes salient the money that is being handed over as part of the verbal interaction. This use was also commented on by several of the newcomers to Ireland. The presentative function is part of now's discourse marker function: it points to something new within a known context.

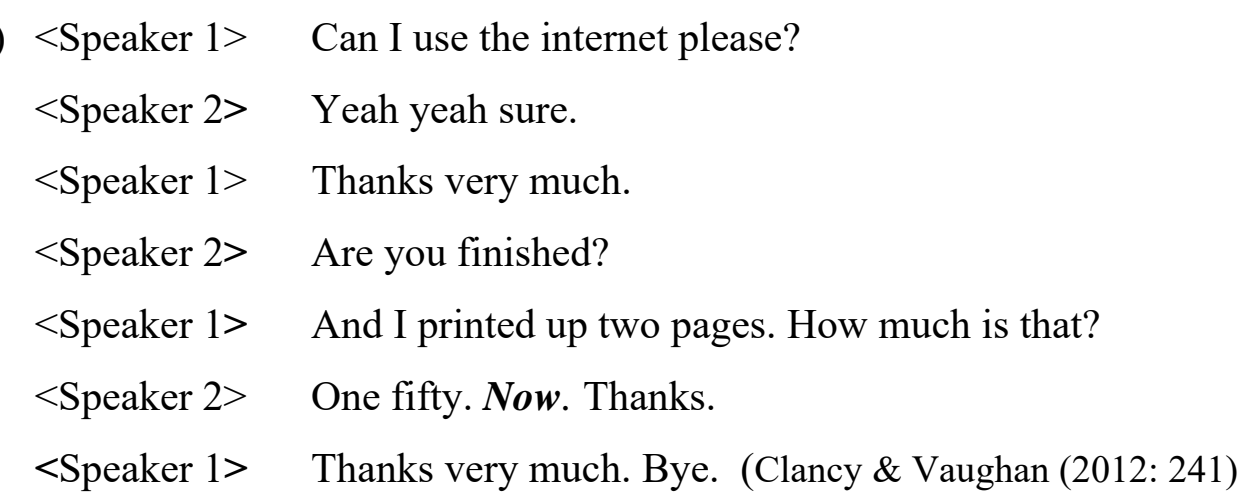

\section{Now in the speech of newcomers to Ireland}


The transcribed audio-recorded interviews with newcomers to Ireland were analyzed quantitatively and qualitatively. Using the software package Wordsmith Tools 6 (Scott 2008), all instances of now were randomly extracted for each interviewee. Each concordance line was then examined individually in order to determine the precise function of each token of now. Below I present first of all the frequency distribution of the various functions of now and then discuss each function in more detail based on a qualitative analysis of the data.

\section{1. The frequency of now in the speech of newcomers to Ireland}

Analysis of the semi-guided interviews with newcomers to Ireland produced a total of 1870 tokens of now (Table 1). As in the case of other corpora, such as the British National corpus and LCIE whose data consist of speech produced by native speakers of English, ${ }^{9}$ temporal uses of now are more frequent than any of the other uses of now. However, in the immigrant data examined here, temporal uses of now by far outweigh other uses of now; they make up $91 \%$ of the total number of now tokens. Compare this with Clancy \& Vaughan's (2012: 234-235) figures based on an analysis of 500 randomly selected occurrences of now from LCIE and the British National corpus, respectively. Less than half (41\%) in the case of LCIE and $61 \%$ of all the now tokens in the British National corpus were found to have a temporal meaning.

There are also broad similarities with respect to the distribution of the other functions of now. In the immigrant data, as in the British National corpus and LCIE, discourse marker uses of now are more frequent than instances where now functions as a pragmatic marker. However, non-temporal uses of now are much less frequent in the immigrant data. They only constitute $5 \%$ and $4 \%$, respectively, of the total instances of now in the immigrant data while they make up about a third each in the LCIE (discourse marker 31\%; pragmatic marker 28\%) and about $37 \%$ and $2 \%$ respectively in the British National corpus. Clancy \& Vaughan (2012) argue that the frequency difference between pragmatic marker now in LCIE and in the British

\footnotetext{
${ }^{9}$ The term native speaker is somewhat controversial as it is often used to mean monolingual. In this paper, I use the term as short-hand for a person who has been using a variety of English as a main or as the only means of communication for most or all of their interactions since childhood.
} 
National corpus is indicative of the fact that this function of now is particular to varieties of Irish English.

Table 1: The distribution of now in the corpus of semi-guided interviews with newcomers to Ireland

\begin{tabular}{|l|l|l|l|l|}
\hline Temporal now & $\begin{array}{l}\text { Discourse } \\
\text { now }\end{array}$ & $\begin{array}{l}\text { Pragmatic } \\
\text { now }\end{array}$ & Presentative now & Total \\
\hline $1708(91.3 \%)$ & $92(5 \%)$ & $63 / 7$ & 2 & 1870 \\
\hline
\end{tabular}

In order to gain a better understanding of the actual distribution of the different instances of now in the semi-guided interviews, I also explored inter-speaker variation. While temporal now was found in all interviews, people's use of discourse and pragmatic marker now differed. Only 20 of the 59 interviewees used both discourse and pragmatic marker now, 15 used only discourse marker now and ten employed only the pragmatic marker now. The absence of non-temporal now may be related to interviewees' comparatively low levels of competence in English in some cases (7). However, this reason cannot explain the absence of non-temporal now in the case of other interviewees as some of them (3) where native speakers of English from the UK and the USA. Further research is required on this issue. Overall, it appears that non-temporal uses of now are established among most of the interviewees though the discourse marker function of now appears to be somewhat better established than the pragmatic function of now. Following Clancy \& Vaughan's (2012) discussion of now, the main reason for this might be that discourse maker now is common to a number of different varieties of English while now as a pragmatic marker is specific to Irish varieties of English. This then suggests that only about half $(50.8 \%)$ of the interviewees have acculturated to some degree to Irish ways of speaking English.

\section{2. Temporal uses of now}


Most interviewees employed between twenty to forty tokens of temporal now in the two interviews and about half of that in single interviews (11). ${ }^{10}$ However, some interviewees (3) used more than 60 instances of now in two one-hour interviews.

Some tokens of now located an activity in the present, usually implicitly or explicitly comparing activities in two different time periods (12).

(12) For example, I helped a little bit with the Lisbon Treaty, which we lost. I am helping with the local election right now. I am the group which is working with the councilors' candidates in the local elections. (2007POL01)

In this function, it occurred in both, sentence or utterance final (12) or initial position, being sometimes modified by elements such as right that emphasize the currency of the activity.

Now was also used to mark temporal relations between utterances or their sequencing order. In this usage, it was often combined with and (13a) to emphasize the successive nature of the events. It also indicates that some event or state has been on-going for a while (13b).

(13) a. I started in reservations just like everybody else and now I am in hotel coordination where I work directly with the hotel managers, tell them their success reports on how they are dealing with our preferred guests, the people who come to our hotels often. (2007US11)

b. I think Finnish [is the language I'm most comfortable in] but I haven't spoken Finnish for a few months now so mostly I speak Polish to the friends in my college, so that would be... (Fin 1)

\section{3. Discourse marker uses of now}

In the immigrant data, discourse marker now is used in similar ways as described for other corpora such as the LCIE corpus (Clancy \& Vaughan 2012), American English

\footnotetext{
10 The recordings also included a number of instances where now occurred in fixed expressions such as now and then, nowadays. These instances were excluded from consideration.
} 
(Schiffrin 1987) and the London-Lund corpus (Aijmer 2002). There are a few instances in which discourse marker now is used to structure discourse (Schiffrin 1987: 232). Take for instance (15). Here the interviewee, a man from Venezuela who had spent most of his adulthood in the US before moving to Ireland, is explaining the role of language knowledge in his current job.

(14) No it is because we are dealing with all of Europe and Asia, South America and the United States so we have to have a language for each country so we have like 16 different languages represented, that is for the reservation part. Now moving into the next level it is a lot different because now I have to interact with a lot of Irish people because the people (2007US11a)

In extract (14), he is comparing different occupational levels (front line service versus managerial level) in his company with respect to the types of people that employees have to deal with and the importance of knowing languages other than English. Now introduces the second part of the comparison - interactions on the managerial level highlighting that it is a subpart of the comparison structure. The use of now in comparisons was not very common overall and mainly found among interviewees coming from the USA, though (15) is an instance from a French interviewee. Further research is needed to determine the distribution of this use of now in varieties of English and other languages.

(15) I wouldn't say I am unfairly treated [unclear] like I got teased and everything for that but nothing that would [unclear]. Like there is always this [unclear] maybe I am very typically French and they are typically Irish [unclear] but it is not too bad this way. Now the customer is another story. (2007FR1)

As a discourse marker, now is also frequently used to mark what Schiffrin (1987: 240) described as pivotal shifts in the participation framework or footing of the interaction. For instance, in example (16) the interviewee is first providing the interviewers with information about an organization and then puts forward her own assessment of the organization's purpose. The assessment part is set off from the former by the use of now which is combined with I think which overtly marks what follows as an opinion. 
(16) $[\ldots]$ when I was studying in university in Ljubljana I was a member of a student organisation called BEST which stands for Build a European Students of Technology and this organisation is again everywhere in Europe except Ireland and UK for some reason

Interviewer 1: They are always different.

Interviewee: [unclear overlapping 00:50:47:11] .org and you will see where it is. Now I think the main thing of this organisation is that, first of all it's technical students and the main activity are summer courses which are 2 week long courses on some technical topic [...] (SLO1)

(17) is an instance where discourse marker now is used to introduce a different footing. Here the interviewee first asserts her acquaintance with Italian chipper families in Dublin before she gives the interviewer privileged information about them. Now marks the shift from a personal experience narrative to a knowledge discourse that highlights her professional engagement with this group of people - she had done a documentary on them for one of her class projects. The change in discourse activity and relationship between the interlocutors is further underscored by ok preceding now and the phrase I will tell you what other people never say about this community.

(17) I know all of them because of this [unclear overlapping 01:27:46:11]. I know them and ok now I will tell you what other people never say about this community. They made a lot of money yes on fish and chips but they made a lot of money on gambling. (2004IT01)

The immigrant corpus also included two tokens (18) that are susceptible to being instances of what Clancy \& Vaughan (2012) referred to as presentative now. Both tokens were uttered by a man from Wales of Irish parents with a strong Irish identity.

(18) a. Interviewee: No I just go back and get all that done over there.

Interviewer 2: Really?

Interviewer 1: Do you? Yes?

Interviewee: Now if I could I would like. I have had to, I would use a kind of a doctor and stuff but I think it's very, it's just I can't figure it out at all really 
like. (2007UK1)

b. Interviewer : How about for example media and newspapers and whatever you read. What kinds of things do you read? Like if you want to find out? Interviewee: BBC.co.uk. Interviewer: You don't read the Irish Times or Interviewee: Ah no I do. Now I would read the Irish Times a bit now.

In both examples now appears to put focus on what follows. However, since the proposition introduced by now adds new information that contrasts with previous information supplied by the interviewee, it might be best to categorize these uses of now as instances of discourse markers now rather than as a presentative now.

\section{4. Pragmatic marker now}

The interviews also include instances where now functions as a pragmatic marker, adding affective meaning to an utterance. As in the case of the LCIE (Clancy \& Vaughan 2012), pragmatic uses of now in the interviews with newcomers to Ireland also occur utterance finally rather than utterance initially. As a pragmatic marker, now generally co-occurs with emotion or affect expressing forms and either emphasizes their affective meaning (19) or mitigates their illocutionary force (21). In example (19a), for instance, now intensifies the emotional content of the verb love, conveying that the interviewee feels very strongly about West Cork and in (19b) it amplifies the negative feelings expressed by gutted.

(19) a. I have been to Galway, Dublin, I haven't been to the North of Ireland yet. I love West Cork now, I have been there a few times, to Clonakilty, it is nice. Dublin I have been to a couple of times, two or three times, a nice city but it is a bigger city. (2007FR01)

b. I think so yes. I think like I am kind of happy kind of here now at the moment like and I would be pretty gutted now like if I was going to lose my job and I did have to go back. I would be kind of, yes. I am just kind of happy how it all kind of worked out and the kind of the friends I made like and where I am at the moment like so, and with the work and stuff like so. (2007uk1) 
There are a few cases in the data where it is not clear whether now functions as a pragmatic marker or as a temporal form, possibly conveying both meanings. In (20), for example, it is not clear whether now intensifies big, or whether reference is made to the fact that Sligo used to be small and has grown significantly in recent years.

(20) Interviewer: And do you like living in Sligo?

Interviewee: Yes.

Interviewer: What do you like about it?

Interviewee: The size of the town, it is a very small town. Some people say to

me, 'Sligo is a very big town now.' I am from a small Polish city with about 400,000 people. (2004POL03)

The use of now as a marker of intensification is less commonly found in the data than its use as a hedging device. Clancy \& Vaughan (2012) argue that now as a mitigator is used to downtone power relationships in face sensitive interactions. Since the interactions in the context of the semi-guided interviews were generally not hierarchical or conflictual in nature, we do not find these kinds of uses of now. However, there are instances where now appears to mitigate the impact or force of an assertion. For instance, in example (21a) the interviewee wants to downtone the implication that he was acting in a completely goal oriented manner as that has overtones of arrogance. In order to mitigate this implication he modified the verb knew with kind of and now which both reduce its force. In (21b), now is mitigating the force of I don't know, suggesting that the interviewee is not completely in the dark about the outcome of the demand; note that she then also moves on to explain that she has already received approval from Ireland.

(21) a. Interviewer: And so is the firm that you are working for is that the one that you had chosen out of the 5 interviews that you did?

Interviewee: It is. I kind of knew now, I knew before I, out of the 10 interviews really like I kind of knew that if this firm had of offered me a place I would have gone for them like because I knew about them before and stuff and they offered a place then like so its. (2007UK1)

b. Interviewee: Yes and that's what I had the contact with the Revenue here 
because I need the letter from them that I am a taxed resident here and it was easy I just called them and they sent it so.

Interviewer: Oh. So and that worked out without any problems?

Interviewee: Well I don't know now it's in process. It worked out on the Irish side I don't know what Slovenia is going to say. (SLO 1)

The pragmatic use of now which Clancy \& Vaughan (2012) identified as distinctive of Irish English was not used by all interviewees and was only used to a small extent (once or twice) by most interviewees who employed it, suggesting that it has not (yet) been widely integrated into these newcomers' language usage.

\section{Conclusion}

This paper examined the uses of now in the speech of people who had relatively recently come (between 2-6 years) to live in Ireland for a variety of reasons. The investigation of semi-guided interviews with 59 people coming from a range of European and non-European countries revealed interesting similarities and differences with respect to the use of now. As in the case of so-called native speakers of varieties of Irish English, temporal uses of now were most prominently represented in the speech of all interviewees. Non-temporal now, by contrast, was much less widely used in the immigrant data than among native speakers of Irish English. While a number of newcomers used pragmatic now, one of its uses which appears to be emblemic of Irish ways of speaking English, they at times employed it slightly differently from the uses described by Clancy \& Vaughan (2012). In the immigrant data it does not only operate on the interlocutor's face wants - mitigation of a threat to the interlocutor's face - but was also used to downtone a threat to the speaker's face. Moreover, although several interviewees highlighted the uniqueness of presentative now, none of them employed it spontaneously in the interview(s).

From the perspective of integration, the low frequency and uneven distribution of the uses of now that appear to be particularly emblemic of Irish English (pragmatic and presentative now) suggest that interviewees have not at all or only weakly acculturated to Irish ways of speaking English. There are two possible reasons for this. On the one hand, low rates of acculturation could be due to lack of sufficient contact with speakers of Irish English. This is indeed an issue that was raised by a 
number of our interviewees. An Italian interviewee, for instance, argued that she did not have any close relationships with Irish nationals because they do not engage with others in that manner (Gilmartin \& Migge in press):

I found quite all the times that it is very easy to hang on with Irish people but then it's not easy to become real friends. To know really who they are, what they want. At some stage you can't be closer to them. (2004IT01)

Another interviewee from the UK argued that he found it hard to make Irish friends because he did not fully understand their socialization patterns.

Interviewee: $[\ldots]$ It is hard sometimes to know where to meet people.

Interviewer: Are there any places that you have found good for meeting people so far?

Interviewee: I have been going to a thing, up to last year, to Toastmasters, which is for public speaking and there is a social side to it as well, so that will be starting again in a couple of weeks so I hope to start going to that again. (2004UK03)

People with Irish partners had more contacts with locals, but often complained that they were not able to make many friends outside of their partner's circle of friends and family.

On the other hand, we also found what could be called a resistance discourse. While many of our interviewees displayed positive attitudes towards Irish English ("it is very endearing' (2007US08)) and were generally happy to actively use features associated with Irish English, others said that they actively avoided such properties because they felt that it undermined their identity (Migge 2012: 322): “And I would get offended probably if somebody said to me I was getting an Irish accent, and that is honest. But that is because being English is an absolute part of who I am, I don't want it to go" (2004UK05). People of African origin and some interviewees from the USA, in contrast, remarked that they avoided Irish features of English because "Irish people generally perceived such uses as mocking: '[...] like, you want to like, speak the way they speak, they think you are, like making jest of them' (N I)" (Migge 2012: 325).

Apart from the degree of contact between newcomers and Irish people, newcomers' attitudes to things Irish and Irish reactions to newcomers' patterns of language use, it is also possible that the nature of the interactional setting impacted on the frequency and distribution of non-temporal uses of now. While an effort was made to emphasise the informal character of the semi-guided interviews (Migge \& 
Gilmartin 2013), they nevertheless differed from the conversational encounters involving familiar interlocutors of a similar age range on which most of the research on the pragmatics of Irish English is based. Further research on the uses of now and other discourse level elements among newcomers to Ireland should thus verify the findings from this study based on an analysis of recordings of naturally occurring conversations.

\section{References}

Aijmer, Karin 2002. English Discourse Particles. Amsterdam: John Benjamins.

Amador-Moreno, Carolina P. 2012. 'A corpus-based approach to contemporary Irish writing: Ross O'Carroll-Kelly's use of like as a discourse marker.' International Journal of English Studies 12(2): 19-38.

Amador-Moreno, Carolina P. 2010. An Introduction to Irish English. London: Equinox.

Amador-Moreno, Carolina P. 2005. 'Discourse Markers in Irish English: an example from Literature.' In The Pragmatics of Irish English, Anne Barron and Klaus P. Schneider (eds), 73-100. Berlin: Mouton de Gruyter.

Anchimbe, Eric \& Janney, Richard. 2011. Postcolonial pragmatics: An introduction. Journal of Pragmatics 43 (6): 1451-1459.

Blakemore, Diane. 1992. Understanding utterances: An introduction to Pragmatics. Oxford: Blackwell.

Brinton, L. J. 1996. Pragmatic Markers in English: Grammaticalisation and Discourse Functions. Berlin, New York: Mouton de Gruyter.

Clancy, Brian. 2011. Complementary perspectives on hedging behaviour in family discourse: The analytical synergy of corpus linguistics and variational pragmatics. International Journal of Corpus Linguistics 16(3): 372-391.

Clancy, Brian. 2005. "You're fat. You'll eat them all: Politeness strategies in family discourse." In The Pragmatics of Irish English (Trends in Linguistics), Anne Barron and Klaus P. Schneider (eds), 177-199. Berlin: Mouton de Gruyter.

Clancy, Brian and Vaughan, Elaine. 2012. "It's lunacy now": A corpus-based pragmatic analysis of the use of 'now' in contemporary Irish English." In New Perspective on Irish English, Bettina Migge and Máire Ní Chiosáin (eds), 225-245. Amsterdam, John Benjamins. 
Corrigan, Karen P. 2010. Irish English, Vol: 1. Northern Ireland. Edinburgh: Edinburgh University Press.

Diskin, Chloe. 2012. "Integration and identity: Acquisition of Irish English by Polish and Chinese migrants in Dublin, Ireland." Newcastle University Working Papers in Linguistics 19.1: 67-89.

Farr, Fiona. 2005. "Relational strategies in the discourse of professional preformance review in an Irish academic environment: The case of language teacher education." In The Pragmatics of Irish English (Trends in Linguistics), Anne Barron and Klaus P. Schneider (eds), 203-233. Berlin: Mouton de Gruyter.

Fraser, Bruce. 1999. “What are discourse markers?” Journal of Pragmatics 31: 931952.

Farr, Fiona, Murphy, Bróna and O’Keeffe, Anne. 2004. The Limerick Corpus of Irish English: Design, description and application. Teanga 21: 5-30.

Farr, Fiona and O'Keeffe, Anne. 2002. "Would as a hedging device in an Irish context: An intra-varietal comparison of institutionalised spoken interaction." In Using Corpora to Explore Linguistic Variation, Randi Reppen, Susan Fitzmaurice and Douglas Biber (eds), 25-48. Amsterdam, Philadelphia: John Benjamins.

Filppula, Markku. 1999. The grammar of Irish English: Language in Hibernian Style. London: Routledge.

Gilmartin, Mary and Migge, Bettina. in press. "European migrants in Ireland: Pathways of integration.” Journal of European Studies.

Hickey, Raymond. 2005. Dublin English: Evolution and Change. Amsterdam: John Benjamins.

Kallen, Jeffrey. 2005. "Silence and mitigation in Irish English discourse." In The Pragmatics of Irish English (Trends in Linguistics), Anne Barron and Klaus P. Schneider (eds), 47-71. Berlin: Mouton de Gruyter.

Lakoff, Robin. 1973. "Questionable answers and answerable questions.” In Issues in Linguistics: Papers in honour of Henry and Renee Kahane, B. B. Kachru, Lees, Y. Malkiel, A. Pietrangeli and S. Saporta (eds), 453-467. Urbana: University of Illinois Press.

Migge, Bettina and Gilmartin, Mary. 2013. "Unbounding migration studies: The intersections of language, space and time." In Migrations: Ireland in a global world, Mary Gilmartin and Allen White (eds.), 199-212. Manchester: Manchester University Press. 
Migge, Bettina. 2012. "Irish English and recent immigrants to Ireland." In New Perspective on Irish English, Bettina Migge and Máire Ní Chiosáin (eds), 311-326. Amsterdam, John Benjamins.

Murphy, Bróna and Farr, Fiona. 2012. “'I'm fine girl, and how are you?': The use of vocatives in spoken Irish English.” In New Perspective on Irish English, Bettina Migge and Máire Ní Chiosáin (eds), 203-223. Amsterdam, John Benjamins.

Müller, Simone. 2005. Discourse markers in native and non-native English Discourse. Amsterdam: John Benjamins.

Nestor, Niamh, Ní Chasaide, Caitoríona and Regan, Vera. 2012. "Discourse 'like' and social identity - a case study of Poles in Ireland." In New Perspective on Irish English, Bettina Migge and Máire Ní Chiosáin (eds), 327-353. Amsterdam, John Benjamins.

O'Keeffe, Anne. 2005. "You've a daughter yourself? A corpus-based look at question forms in an Irish radio phone-in”. In The Pragmatics of Irish English (Trends in Linguistics), Anne Barron and Klaus P. Schneider (eds), 339-365. Berlin: Mouton de Gruyter.

Schiffrin, Deborah. 1987. Discourse markers. Cambridge: Cambridge University Press.

Schourup, Lawrence. 2011. "The discourse marker now: A relevance-theoretic approach. Journal of Pragmatics 43: 2110-2129.

Romero Trillo, Jésus. 2002. "The pragmatic fossilization of discourse markers in nonnative speakers of English.” Journal of Pragmatics 34: 769-784.

Scott, M. 2008. Wordsmith Tools. Oxford: Oxford University Press.

Svartvik, John. 1980. "Well in conversation.” In Studies in English linguistics for Randolph Quirk, Sidney Greenbaum, Geoffrey Leech \& Jan Svartvic (eds.), 167177. London: Longman, 